\title{
Enteropathy and brain hyper-excitability in DPPX ataxia
}

\author{
Pattrick M MRCP ${ }^{1}$, Sarrigiannis PG MD' ${ }^{1}$, Kruger $S M^{3}$, Davies B FRCP ${ }^{4}$, Hoggard N PhD², \\ Irani SR DPhil ${ }^{5}$, Unwin $Z^{1}$, Zis $\mathrm{P} \mathrm{PhD}^{1}$, Blackburn DJ PhD¹, Hadjivassiliou M MD \\ ${ }^{1}$ Academic Department of Neurosciences and ${ }^{2}$ Department of Neuroradiology, Sheffield \\ Teaching hospitals NHS Trust and University of Sheffield, Sheffield, UK, ${ }^{3}$ Department of \\ Psychiatry and ${ }^{4}$ Department of Neurorehabilitation, Doncaster and South Humber NHS \\ Trust, Doncaster, UK, ${ }^{5}$ Nuffield Department of Clinical Neurosciences, University of Oxford, \\ Oxford, UK.
}

Submission type: article (smaller scope study)

Title Character count: 49

Number of tables: 1

Number of figures: 1

Word count text: 660

Corresponding author: Marios Hadjivassiliou

m.hadjivassiliou@sheffield.ac.uk

Academic Department of Neurosciences, Sheffield Teaching Hospitals NHS Trust,

Royal Hallamshire Hospital, Glossop Road, Sheffield S10 2JF, UK

Tel +441142712502 
Dear Sirs,

DPPX antibody-related ataxia (DPPX-ARA) was first described in 2013 [1]. The 4 patients reported presented with agitation, hallucinations, confusion, myoclonus, tremor and seizures. Three patients had a prodromal diarrheal illness. DPPX is an auxiliary, regulatory protein of the Kv4.2 potassium channel, involved in increasing the activity and surface expression of the Kv4.2 channel [2]. This channel serves in attenuating the back propagation of action potentials under resting conditions. Its internalisation, due to DPPX-antibodies and their effect on neurones, is thought to be the pathophysiological basis of autoantibody-induced CNS-hyperexcitability responsible for this disease [3, 4].

We present 3 cases with DPPX-ARA that underwent detailed neurophysiological assessments alongside cerebellar MR Spectroscopy pre and post immunotherapy. Two patients also had gastroscopy and duodenal biopsies as part of investigation for severe weight loss.

Two patients presented with ataxia and tremor. The third with apathy, depression and visual hallucinations. All patients had lost significant weight $(15,45$ and $60 \mathrm{~kg})$ prior to the neurological presentation. Clinical examination demonstrated irregular tremor affecting the arms. They all startled to noise. Two had horizontal nystagmus and no significant limb ataxia. All had gait ataxia. Suspicion for DPPX-ARA was raised because of $60 \mathrm{Kg}$ weight loss. The positive result prompted us to recall and test the female patient that had been seen several years before with suspected immune ataxia. She had lost $45 \mathrm{Kg}$. Because of the weight loss both these patients underwent gastroscopy and duodenal biopsies despite no serological evidence of celiac disease. The biopsies showed increased intraepithelial lymphocytes in both and in addition villus atrophy and crypt hyperplasia in one. Gluten-free diet, however did not help the ataxia. This argues against these patient having gluten ataxia.

Electrophysiological assessment using EEG/EMG polygraphy were done to assess the myoclonus. Data were analysed with the technique of jerk-locked averaging (JLA) [6]. All 
patients underwent somatosensory evoked potentials (SEP) to assess the possibility of cortical hyperexcitability and long loop reflexes, according to published methodology $[7,8]$. The recordings from the first case showed that the irregular jerky postural and kinetic upper limb myoclonus was of cortical origin (figure 1, A). In addition, presentation of unanticipated loud auditory stimuli on polygraphy recordings showed evidence of exaggerated startle. EEG/EMG polygraphy recordings from case 2 showed evidence of exaggerated startle. In addition, JLA analysis showed evidence suggestive a cortical generator for the myoclonus (figure 1, B). In case 3, the inconspicuous myoclonus captured from the legs showed short EMG bursts with durations at or below $75 \mathrm{~ms}$ with co-contraction of agonist/antagonist on the JLA data but without any associated cortical transients preceding the onset of the averaged EMG myoclonic discharges. SEP were normal in all patients.

All patients underwent serial MR spectroscopy (MRS) of the cerebellum to monitor response to immunotherapy. Only one had evidence of mild atrophy of the cerebellar vermis. All 3 had abnormal MRS (table 1). Two patients were treated with mycophenolate. The third patient was initially treated with plasma exchange, steroids and rituximab and then maintenance with mycophenolate. All responded well to immunotherapy on clinical grounds. There was significant increase in the NAA/Cr ratio in the first 2 patients and no significant change in the $3^{\text {rd }}$ patient.

This report provides novel neurophysiological, cerebellar MRS and small bowel biopsy data on DPPX-ARA. We have identified evidence of an enteropathy and its presence may explain the prominent gastrointestinal symptoms and marked weight loss which is a feature in DPPA-ARA. A previous study used serum from a patient with DPPX-ARA to show evidence of hyper-excitability of the enteric nervous system [4].

We suspect that the hyper-excitability observed in these cases could be the result of loss of inhibition due to cerebellar dysfunction. Using MR spectroscopy of the cerebellum we were 
able to confirm cerebellar dysfunction in all and also to show improvement in MRS following immunotherapy.

Detailed neurophysiological examination confirmed evidence of brain hyper-excitability manifesting with cortical myoclonus and exaggerated startle. It is increasingly recognised that in immune mediated ataxias brain hyper-excitability can be a prominent feature and could be the result of loss of inhibition due to cerebellar pathology [9]. 
References

1 Boronat B, Jeffrey M, Gelfand M et al. Encephalitis and antibodies to DPPX, a subunit of Kv4.2 potassium channels. Ann Neurol 2013;73(1):120-8.

2 Tobin W, Lennon V, Komorowki L, et al. DPPX potassium channel antibody. Neurology 2014;83(20):1797-803.

3 Hara M, Arino H, Sabater L, et al. DPPX antibody-associated encephalitis: Main syndrome and antibody effects. Neurology 2017;88(14): 1340-1348.

4 Peipgras J, Holtje M, Klaus M, et al. Anti-DPPX encephalitis. Pathogenic effects of antibodies on gut and brain neurons. Neurology 2015;85(10): 890-897.

5 Currie S, Hadjivassiliou M, Craven I, et al. Magnetic resonance spectroscopy of the brain. Postgrad Med J. 2013:2;89(1048):94-106.

6 Shibaski H, Hallett M. Electrophysiological studies of myoclonus. Muscle Nerve. 2005 $31(2): 157-74$.

7 Cassim F, Houdayer E. Neurophysiology of myoclonus. Clinical Neurophysiology. 2006 36(5-6):281-91

8 Croccu G, Aminoff MJ, Curio G et al. Recommendations for the clinical use of somatosensory-evoked potentials. Clinical Neurophysiology. 2008. 119(8):1705-1719.

9 Hadjivassiliou M, Graus F, Honnorat J et al. Diagnostic criteria for primary autoimmune cerebellar ataxia-guidelines from an international task force on immunemediated cerebellar ataxias. The cerebellum https://doi.org/10.1007/s12311-020-01132-8 
Table 1: Clinical characteristics and treatment outcomes in 3 patients with DPPX-ARA

\begin{tabular}{|c|c|c|c|c|c|c|c|c|}
\hline \multirow{2}{*}{$\begin{array}{l}\text { Patient } \\
\text { age/sex } \\
\text { (age at } \\
\text { onset) }\end{array}$} & \multirow[t]{2}{*}{$\begin{array}{l}\text { Prodromal } \\
\text { symptoms }\end{array}$} & \multirow[t]{2}{*}{$\begin{array}{l}\text { Main neurological } \\
\text { symptoms/signs }\end{array}$} & \multirow[t]{2}{*}{ Duodenal biopsy } & \multirow{2}{*}{$\begin{array}{l}\text { Ancillary tests } \\
\text { (all normal of } \\
\text { negative) }\end{array}$} & \multirow[t]{2}{*}{$\begin{array}{l}\text { Immunotherapy } \\
\text { (effect) }\end{array}$} & \multirow{2}{*}{$\begin{array}{l}\text { Months of FU } \\
\text { post DPPX } \\
\text { diagnosis. }\end{array}$} & \multicolumn{2}{|c|}{$\begin{array}{l}\text { Longitudinal cerebellar MR } \\
\text { spectroscopy from the vermis }\end{array}$} \\
\hline & & & & & & & Date of examination & $\begin{array}{l}\mathrm{NAA} / \mathrm{Cr} \\
\text { ratio } \\
\text { (normal } \\
>1 \text { ) }\end{array}$ \\
\hline \multirow[t]{3}{*}{$58 / \mathrm{M}(55)$} & \multirow[t]{3}{*}{$\begin{array}{l}\text { Itching, vivid } \\
\text { dreams, unsteady } \\
60 \mathrm{Kg} \text { weight loss. }\end{array}$} & \multirow[t]{3}{*}{$\begin{array}{l}\text { Nocturnal } \\
\text { myoclonic jerks, } \\
\text { hyperreflexia, } \\
\text { nystagmus, gait } \\
\text { ataxia }\end{array}$} & \multirow{3}{*}{$\begin{array}{l}\text { Increased } \\
\text { intraepithelial } \\
\text { lymphocytes. } \\
\text { No crypt } \\
\text { hyperplasia or } \\
\text { villious atrophy }\end{array}$} & \multirow{3}{*}{$\begin{array}{l}\begin{array}{l}\text { Gluten } \\
\text { sensitivity } \\
\text { serology, }\end{array} \\
\text { ANA, ANCA, } \\
\text { LGI1, } \\
\text { CASPR2, } \\
\text { VGCC, Glycine } \\
\text { receptor } \\
\text { antibody }\end{array}$} & \multirow[t]{3}{*}{$\begin{array}{l}\text { Mycophenolate; } \\
\text { (improved tremor and } \\
\text { stabilised ataxia) }\end{array}$} & \multirow[t]{3}{*}{24} & $\begin{array}{l}\text { September } 2014 \\
\text { baseline }\end{array}$ & 0.95 \\
\hline & & & & & & & $\begin{array}{l}\text { September } 2018 \\
\text { post myophenolate }\end{array}$ & 0.99 \\
\hline & & & & & & & $\begin{array}{l}\text { June } 2019 \\
\text { on mycophenolate }\end{array}$ & 1.05 \\
\hline \multirow[t]{2}{*}{$62 / \mathrm{M} \mathrm{(58)}$} & \multirow{2}{*}{$\begin{array}{l}\text { Visual } \\
\text { hallucinations, } \\
\text { restless sleep, } \\
\text { marked anxiety, } \\
\text { apathy and } \\
\text { irritability, } \\
\text { 15kg weight loss }\end{array}$} & \multirow{2}{*}{$\begin{array}{l}\text { Exaggerated } \\
\text { startle, allodynia, } \\
\text { hyperreflexia, } \\
\text { unsteady gait, } \\
\text { myoclonus, } \\
\text { cognitive decline } \\
\text { (ACE-R 78/100). }\end{array}$} & \multirow[t]{2}{*}{ Normal } & \multirow{2}{*}{$\begin{array}{l}\text { LGI1,CASPR2, } \\
\text { NMDA, gluten } \\
\text { sensitivity } \\
\text { serology, HIV, } \\
\text { anti-GAD } \\
\text { CSF }\end{array}$} & \multirow[b]{2}{*}{$\begin{array}{l}\text { Rituximab. } \\
\text { (cognitive } \\
\text { improvement, } \\
\text { myoclonus and } \\
\text { excessive startle } \\
\text { resolved) }\end{array}$} & \multirow[t]{2}{*}{24.} & $\begin{array}{l}\text { October } 2017 \\
\text { baseline }\end{array}$ & 0.69 \\
\hline & & & & & & & $\begin{array}{l}\text { October } 2019 \\
\text { on mycophenolate }\end{array}$ & 0.79 \\
\hline \multirow[t]{3}{*}{$59 / F(49)$} & \multirow[t]{3}{*}{$\begin{array}{l}\text { Headache, } \\
\text { unsteady, } \\
\text { tiredness, anxiety, } \\
45 \mathrm{Kg} \text { weight loss. }\end{array}$} & \multirow[t]{3}{*}{$\begin{array}{l}\text { Ataxia, } \\
\text { myoclonus, } \\
\text { hyperreflexia, } \\
\text { nystagmus }\end{array}$} & \multirow[t]{3}{*}{$\begin{array}{l}\text { Increased intra- } \\
\text { epithelial } \\
\text { lymphocytes, } \\
\text { villious atrophy, } \\
\text { crypt hyperplasia }\end{array}$} & \multirow{3}{*}{$\begin{array}{l}\text { Gluten } \\
\text { sensitivity } \\
\text { serology } \\
\text { ANA, ANCA, } \\
\text { LGI1, } \\
\text { CASPR2, } \\
\text { VGCC, Glycine } \\
\text { receptor } \\
\text { antibody }\end{array}$} & \multirow{3}{*}{$\begin{array}{l}\text { Prednisolone, } \\
\text { Mycophenolate } \\
\text { (reduction in } \\
\text { myoclonus, less } \\
\text { anxious) }\end{array}$} & \multirow[t]{3}{*}{18} & $\begin{array}{l}\text { July } 2013 \\
\text { baseline }\end{array}$ & 0.76 \\
\hline & & & & & & & $\begin{array}{l}\text { June } 2018 \\
\text { Pre-treatment }\end{array}$ & 0.74 \\
\hline & & & & & & & $\begin{array}{l}\text { February } 2019 \\
\text { Post treatment } \\
\text { (mycophenolate) }\end{array}$ & 0.78 \\
\hline
\end{tabular}


Funding: none

Conflicts of interest: The authors have no conflicts of interest to disclose

\section{Ethical standards}

This article summarizes observational case series of 3 patients with DPPX-ARA being managed at the Sheffield Ataxia Centre (SAC), Sheffield UK. The South Yorkshire Research Ethics Committee has confirmed that no ethical approval is indicated given that immunosuppression is a recognized treatment for DPPX-ARA and that all investigations/interventions were clinically indicated and did not form part of a research study.

Data access, responsibility, and analysis

The corresponding author had full access to all the data and takes responsibility for the integrity of the data and the accuracy of the data analysis. 